Egyptian J. Desert Res., 69, No. 1, 101-121 (2019)

\title{
IMPACT OF BIO-FERTILIZER AND TIO NANOPARTICLES SPRAY ON GROWTH, PRODUCTIVITY AND PICKLE QUALITY OF TURNIP CROP (BRASSICA RAPA)
}

\author{
Mohamed A.M. El-Sagan ${ }^{1^{*}}$ and Amira M. Shokry ${ }^{2}$ \\ ${ }^{1}$ Vegatable Unit, Department of Plant Production, Desert Research Center, El- \\ Matareya, Cairo, Egypt \\ ${ }^{2}$ Agricultural Industrialization Unit, Department of Plant Production, Desert \\ Research Center, El-Matareya, Cairo, Egypt \\ *E-mail: drm_elsagan@yahoo.com
}

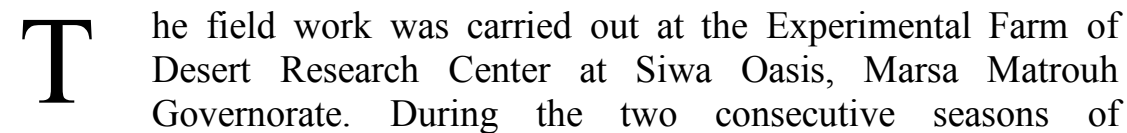
$2015 / 2016$ and $2016 / 2017$, the experiments were conducted to study the effect of bio-fertilizers namely Nitroben at the rate of $1.5 \mathrm{~kg} / \mathrm{fed}$, Phosphorin at the rate of $1.5 \mathrm{~kg} / \mathrm{fed}$ and a mixture of them and nanotitanium dioxide $\left(\mathrm{TiO}_{2}\right)$ as foliar application at the rate of 0,1 and 2 $\mathrm{mg} / \mathrm{L}$ on growth, yield, chemical composition and pickle quality of turnip plant, purple top white glop cv. grown in sandy soil conditions. Results revealed that the highest values of growth, yield parameters and chemical contents were clear with bio-fertilizer application compared to control treatment (without application). No significant differences were found between bio-fertilizer treatments on most parameters. The highest values of growth, yield parameters and chemical contents were obtained with $\mathrm{TiO}_{2}$ application at the rate $2 \mathrm{mg} / \mathrm{L}$, followed by rate of $1 \mathrm{mg} / \mathrm{L}$ as compared to control treatment (without application). No significant differences were found among $\mathrm{TiO}_{2}$ nanoparticle treatments on most parameters. Regarding to the effect of the bio-fertilizers and $\mathrm{TiO}_{2}$ treatments on turnip pickle quality, it was found that, Nitroben and Phosphorin bio-fertilizers and $\mathrm{TiO}_{2}$ spray had the more acceptable sensory scores and excellent texture characteristics. Also, investment ratio had been calculated.

Keywords: Trunip, biofertilizer, $\mathrm{TiO}_{2}$ nanoparticles, growth, yield, chemical composition, pickling, sensory properties 
Siwa Oasis is located in the northern part of the Western Desert of Egypt. The total cultivated area is (20940 fed). It is characterized by hot and dry climate conditions. The Oasis displays numerous landforms: salt marshes, salt lakes and cultivated lands. The main activity in Siwa Oasis is agriculture which is depending on palm date and olive trees and its industries such as Packaging of palm dates, extract olive oil and pickling olives.

Turnip (Brassica rapa) is a member of the cruciferous family, turnip is a plant widely cultivated for its enlarged roots and for the foliage. Both its enlarged roots and foliage are very rich in minerals, vitamin $\mathrm{A}$ and $\mathrm{C}$. They also contain about $92.3 \%$ water, $0.8 \%$ protein, $0.2 \%$ fats, $6 \%$ carbohydrates and $0.7 \%$ ash (Thompson and Kelly, 1957). Turnip used as salad, cooked and pickled. Also, it had an oilseed for medical Industries (Khashayar, 2007). Turnip is a short duration rapid season and as a fodder, it is palatable, also it is rich in available carbohydrate. As will as it is also succulent and more digestible

Bio-fertilizers, help in augmenting the crop productivity through effective mobilization of major plant nutrients like N, P and $\mathrm{K}$ and other minor nutrients needed by the crop. These beneficial microorganisms are also known to secrete plant growth promoting substances like IAA, GA, cytokinins, vitamins for the improvement of crop growth, yield and for quality produce (Natarajan, 2007; Sreenivasa et al., 2010; Kumar et al., 2013 and Mehdizadeh et al., 2013).

Application of nitrogen along with the bio-fertilizer significantly increased morphological, yield and quality characters as compared to application of nitrogen without bio-fertilizer (Bashyal, 2011). Also, bio-fertilizer showed higher vegetative growth parameters (plant height; leaves and branches number; as well as fresh and dry weight of leaves and stems); yield and its components; physical heads quality (weight, diameter and height); vitamin $\mathrm{C} ; \mathrm{N} ; \mathrm{P}$ and $\mathrm{K}$ in tissues of broccoli leaves and heads than the untreated plants (Zaki et al., 2012). Moreover, the development and use of bio-fertilizers is considered as an important alternative for the partial or total substitution of synthetic fertilizers (Aghili et al., 2014).

As for, bio-fertilizer is low cost input, compatible with chemical fertilizers and pesticides, safe to crop and users both, eco-friendly and pose no danger to the environment; also minimizes the pollution by excessive uses of chemical fertilizer (Abul Hossain, 2012).

Fawzy et al. (2012) studied pepper plants and found that, using biofertilizers Microbin and Biogen significantly increased the vegetative growth characters, increased chlorophyll content of leaves, total amount of N, P and K content of leaves, also increased chemical properties (T.S.S, Acidity, Ascorbic acid and Carotenoids) of fruits. Molla et al. (2012) on tomatoes found that, vegetative growth, such as plant height, number of leaves and branches per plant

Egyptian J. Desert Res., 69, No. 1, 87-107 (2019) 
was significantly influenced by the application of bio-fertilizers alone or in combination with NPK.

Nanotechnology permits broad advances in agricultural research, such as production science and technology, conversion of agricultural wastes to energy through enzymatic nanobioprocessing, disease prevention and treatment in plants using various nanocides (Carmen et al., 2003)

Nanoparticles are new material, which are stimulates crop growth, improves soil environment and promotes crop growth metabolism ( $\mathrm{Lu}$ et al. 2002). Nanoparticles (nano-scale particles $=$ NSPs) are atomic or molecular aggregates with at least one dimension between 1 and $100 \mathrm{~nm}$ (Roco, 2003), that can drastically modify their physical-chemical properties when compared to the bulk material (Nel et al., 2006). Nanoparticles have a large specific surface area that can provides for a good level of reactivity and this character facilitates effective absorption of fertilizers and pesticides at nanoscale (Sheykhbaglou et al., 2010).

Titanium dioxide $\left(\mathrm{TiO}_{2}\right)$ is a non-toxic, white pigment, it is use in manufacture of paints, plastics, paper, ink, rubber, textile, cosmetics, leather, and ceramics (Moore, 1997). Also, Barley (2003) reported that $\mathrm{TiO}_{2}$ is considered to be non-toxic and harmless, that is approved for the use in food up to $1 \%$ of product final weight. Studies reported that nano- $\mathrm{TiO}_{2}$ can promote plant photosynthesis and nitrogen metabolism and then greatly improve growth at a suitable concentration (Hong et al., 2005; Zheng et al., 2005 and Yang et al., 2007). Moreover, Gao et al., (2008) revealed that treated plant by nano-anatase $\mathrm{TiO}_{2}$, Rubisco carboxylase activity was 2.67 times that of control.

They also reported that the application of $\mathrm{TiO}_{2}$ significantly reduced incidence of rice blast and tomato mould with a correspondent $20 \%$ increase in grain weight due to the growth promoting effect of $\mathrm{TiO}_{2}$ nano-particles (NPL 2002). $\mathrm{TiO}_{2}$ nanoparticles increasing of light energy absorption by photosystem I and transfer of it into the photosystem II, transfer of electrons and also by development of photolysis of water and releasing of oxygen, caused an increasing in the yield of plant (Mingyu et al., 2007).

Food and Agriculture Organization (FAO) and World Health Organization (WHO) recommended a daily intake dose of vegetable and fruits to prevent diseases, therefore, continued attention to increasing vegetables consumption is an important way to improve nutrition and reduce disease risk (Ann et al., 2000). Fruits and vegetables are easily perishable due to their high moisture content, so, processing techniques considered to be the optimum solution to extend their shelf life, moreover, provide human with their nutritional needs. 
Pickling is one of the most important food preservation techniques that reducing food spoilage, increasing availability beyond the season and produce products with an excellent sensory property (Das et al., 2016). Market demand for pickled vegetables has increased due to their rich nutritional properties, better organoleptic characteristics, therefore, the pickled vegetables become the ideal candidates for the commercial scale by the local food movement participants (Vatansever et al., 2017). So, the aim of this study is evaluated the impact of bio-fertilizer and $\mathrm{TiO}_{2}$ nanoparticles spray on growth and productivity of turnip cultivar, as well as, the quality of processed pickled turnip.

\section{MATERIALS AND METHODS}

The field work was carried out at Siwa Research Station of the Desert Research Center, Marsa Matrouh Governorate, during the two consecutive winter seasons of 2015/2016 and 2016/2017. The experiments were conducted to study the effect of bio-fertilizers which were purchased from the General Authority of Agricultural Funds and Equalization, namely Nitroben (non symbiotic nitrogen fixing bacteria), Phosphorin (phosphate solubilizing bacteria) and Nano titanium dioxide as foliar application on growth, yield and chemical composition of turnip plants, Purple top white glop cv. grown in sandy soil conditions.

Twelve treatments were used which were the combination of four biofertilizers i.e., Nitroben at the rate $1.5 \mathrm{~kg} / \mathrm{fed}$; Phosphorin at the rate $1.5 \mathrm{~kg} / \mathrm{fed}$; Mixing (Nitroben + phosphorin at the rate $1.5 \mathrm{~kg} / \mathrm{fed}$, for each one) were added during land preparation and control treatment (without application) and three levels of nano titanium dioxide foliar application i.e., $(1 ; 2 \mathrm{mg} / \mathrm{L}$ and control spray by tap water). The physical and chemical soil characteristics of the studied site were determined according to Page et al., (1982) and Klute (1986) respectively, as recorded in table (1). The chemical analysis of irrigation water was carried out using the standard method of Page et al. (1982) and presented in table (2)

Table (1). Some physical and chemical properties of the experimental soil site.

\begin{tabular}{|c|c|c|c|c|c|c|c|c|c|c|}
\hline \multirow{2}{*}{$\begin{array}{c}\text { Soil } \\
\text { depth } \\
\text { (cm) }\end{array}$} & \multirow{2}{*}{$\begin{array}{c}\text { Texture } \\
\text { class }\end{array}$} & \multicolumn{3}{|c|}{$\begin{array}{c}\text { Soluble anions } \\
(\mathrm{me} / \mathrm{L})\end{array}$} & \multirow{2}{*}{$\begin{array}{c}\text { pH } \\
\text { soil } \\
\text { paste }\end{array}$} & \multirow{2}{*}{$\begin{array}{c}\text { E.C. } \\
\left(\mathrm{dSm}^{-1}\right)\end{array}$} & \multicolumn{4}{|c|}{ Soluble cations $(\mathrm{me} / \mathrm{L})$} \\
\hline & & $\mathrm{HCO}_{3}^{-}$ & $\mathrm{SO}_{4}{ }^{=}$ & $\mathrm{Cl}^{-}$ & & & $\mathbf{C a}^{++}$ & $\mathbf{M g}^{++}$ & $\mathrm{Na}^{+}$ & $\mathbf{K}^{+}$ \\
\hline $0-25$ & $\begin{array}{l}\text { Sandy } \\
\text { loam }\end{array}$ & 0.75 & 0.85 & 4.25 & 6.7 & 0.58 & 1.15 & 0.45 & 3.92 & 0.33 \\
\hline
\end{tabular}

Egyptian J. Desert Res., 69, No. 1, 87-107 (2019) 
Table (2). Chemical analysis of the irrigation water.

\begin{tabular}{cccccccccc}
\hline \multirow{2}{*}{ Samples } & $\mathbf{p H}$ & $\begin{array}{c}\text { E.C. } \\
\left(\mathbf{d S m}^{-1}\right)\end{array}$ & \multicolumn{3}{c}{ Soluble cations (me/L) } & \multicolumn{3}{c}{ Soluble anions (me/L) } \\
\cline { 4 - 9 } & $\mathbf{C a}^{++}$ & $\mathbf{M g}^{++}$ & $\mathbf{N a}^{+}$ & $\mathbf{K}^{+}$ & $\mathbf{H C O}_{3}^{-}$ & $\mathbf{S O}_{4}{ }^{-}$ & $\mathbf{C l}^{-}$ \\
\hline \multirow{2}{*}{$1^{\text {st. }}$ season } & 7.1 & 5.54 & 10.1 & 13.32 & 39.4 & 1.17 & 9.35 & 15.1 & 39.5 \\
& & & & & & & & & \\
\hline
\end{tabular}

pH: Acidity, E.C.: Electrical conductivity, $\mathrm{dSm}^{-1}$ : decimeter per meter

Organic manure was added at the rate of $20 \mathrm{~m}^{3} / \mathrm{fed}$, and calcium superphosphate $\left(15.5 \% \mathrm{P}_{2} \mathrm{O}_{5}\right)$ at the rate of $350 \mathrm{~kg} / \mathrm{fed}$, were added during land preparation. Nitrogen fertilizer as ammonium sulphate $(20.5 \% \mathrm{~N})$ and potassium sulphate $\left(48 \% \mathrm{~K}_{2} \mathrm{O}\right)$ at the rate of 250 and $150 \mathrm{~kg} / \mathrm{fed}$, respectively. Nitrogen and potassium quantities were divided and applied with irrigation every week during growing season started after 15 days from planting. Turnip seeds were planted in first week of November through the two growing seasons respectively. Turnips are precision seeded in multiple rows on raised beds that range from $(70-75 \mathrm{~cm})$ wide and $25 \mathrm{~m}$ long, with 4 rows to $10-15 \mathrm{~cm}$ apart and plants in rows spaced $(7.5-10 \mathrm{~cm})$ apart. Planting density is important because the root quality suffers when turnips are crowded and irrigated with drip irrigation system. All agricultural practices were as Egyptian ministry of agriculture recommendation.

\section{Preparation of $\mathrm{TiO}_{2}$ Nanoparticles}

Titanium nanoparticles $\left(\mathrm{TiO}_{2}\right)$ were prepared by laser ablation of a Titanium plate $(99.9 \%$ in purity) in $10 \mathrm{ml}$ deionized water. Q-switched Nd:YAG (Quantel) pulse laser generating $8 \mathrm{~ns}$ pulses at the wavelength of $1064 \mathrm{~nm}$ with the repetition rate of $10 \mathrm{~Hz}$ and the energy density was $400 \mathrm{~J} / \mathrm{cm} 2$, was focused using a $100 \mathrm{~mm}$ focal length lens on the metal plate immersed in water according to Siuzdak et al. (2014). The required quantities were prepared at the Laser Institute of Cairo University.

\section{Vegetative Growth Parameters}

Vegetative growth samples were taken after 60 days from planting, four plants were selected randomly from each plot and the following characteristics were recorded i.e., plant fresh weight $(\mathrm{g})$, plant height $(\mathrm{cm})$, leaves number per plant, dry matter percent, leaf area was measured using an automatic leaf area meter AREAMETR (cl-202), total chlorophyll in plant leaves were measured using Minolta chlorophyll meter (model SPAD 502). Chlorophyll measurements 
were made using the recently fully expanded leaf and 5 readings were averaged per experimental unit according to A.O.A.C. (1990).

\section{Root and Yield Parameters}

At harvest time stage (90 days from planting date), a sample of 20 plant were randomly taken from each experimental plot for characteristics, i.e., plant weight, average root fresh weight and dry matter percentage, root diameter and length were recorded. In addition to root yield for $\mathrm{m}^{2}$ and total yield (ton/fed).

\section{Chemical Constituents}

Three samples of root from each experimental unit were taken and oven dried at $70^{\circ} \mathrm{C}$ until stable weight then grinded to fine particles and used to determine chemical contents $\mathrm{N}, \mathrm{P}$ and $\mathrm{K}$. Phosphorus was determined using the colorimetric method for phosphorus content using spectrophotometer according to Cottenie et al. (1982), Total nitrogen was determined using the modified Micro Kjeldahl method. Potassium percentage was measured using Flame photometer by method as described by Brown and Lilliland (1964). Total carbohydrates were determined according to A.O.A.C. (1990).

\section{Processing of Turnip Pickle}

Turnips of the best treatments were processed as a pickle according to (Yamani et al., 1999), where turnip of each treatment was hand-washed, cut into pieces and put into glass jars. A brine containing $6 \%(\mathrm{w} / \mathrm{v})$ sodium chloride was then added to the jars, the final pack-out ratio was about $55: 45(\mathrm{w} / \mathrm{w})$. A thin semi-rigid plastic sheets were pressed over them in order to prevent the turnip pieces from rising. The jars were then closed and left at room temperature $\left(25 \pm 2^{\circ} \mathrm{C}\right)$ for three weeks.

\section{Texture Analysis}

The Hardness $(\mathrm{N})$ of the turnip pickles treatments were estimated using Instron Universal Testing Machine (Model 2519-105, USA) at Research Park (CURP), Faculty of Agriculture, Cairo University. Six test from each sample were taken. The machine test speed was $200 \mathrm{~mm} / \mathrm{min}$ and hardness $(\mathrm{N})$ was recorded electronically.

\section{Sensory Evaluation}

Sensory evaluation of the turnip pickles treatments were carried out by ten panelists at Agricultural Industrialization Unit, Desert Research Center, Cairo, Egypt. The panelists were asked to evaluate appearance, color, taste, texture and overall acceptability using 10-point scale for grading the quality of

Egyptian J. Desert Res., 69, No. 1, 87-107 (2019) 
samples as described by A.A.C.C. (2000). The panelists were asked to note any differences between the pickled turnips treatments, without knowing the identity of the treatments. All analyses were performed in triplicate and data were subjected to analysis of variance (ANOVA) $(P<0.05)$.

\section{Investment Ratio}

Investment Ratio (IR) = (total revenue, LE / total cost, LE) for fresh yield and pickle production following Rana et al. (1996).

\section{Experimental Design and Statistical Analysis}

The experimental treatments were arranged in split plot design with three replicates, the main plots were assigned for bio-fertilizer amendments, whereas, foliar spray rates were randomly arranged in the sub plots. Statistical analyses of obtained data were done according to Thomas and Hills (1975).

\section{RESULTS AND DISCUSSION}

\section{Vegetative Growth}

Growth parameters i.e., chlorophyll content, leaf area, plant height and weight, no. of leaves/plant and shoot dry matter percent and were presented in tables (3 and 4). Obtained results indicated that there are significant positive effects for both bio-fertilizer and foliar spray application on all investigated growth parameters. Presented data in the tables (3 and 4) show the following:

1. The highest values of leaf area, plant height and weight, no. of leaves/plant were clear with bio-fertilizer mixture (nitroben + phosphorin) treatment, but the highest values of shoot dry matter percent were clear with the bio-fertilizer phosphorin treatment. Also, no significant differences among all treatments for total chlorophyll parameter in both growing seasons. These results are in the same line with those reported by Fawzy et al. (2012) and Molla et al. (2012), who indicated that bio-fertilizers significantly increased the vegetative growth characters (plant length, number of leaves and stems per plant) of pepper and tomato plants.

2. The highest values of plant height and weight, no. of leaves/plant; shoot dry matter percent; chlorophyll content and leaf area were recorded with $\mathrm{TiO}_{2}$ nanoparticles spray at the rate of $2 \mathrm{mg} / \mathrm{L}$, followed by the rate of 1 $\mathrm{mg} / \mathrm{L}$. However, no significant differences appeared among all $\mathrm{TiO}_{2}$ nanoparticles spray treatments in both growing seasons. The positive effect of $\mathrm{TiO}_{2}$ nanoparticles application may be due to that it increases 
the photosynthetic activities in plants. The results recorded in tables (3 and 4) are in the same line with those obtained by Zheng et al. (2005), Hong et al. (2005) and Yang et al. (2007), who reported that nano- $\mathrm{TiO}_{2}$ can promote plant photosynthesis and nitrogen metabolism and then greatly improve growth characters.

3. The interaction between the two studied factors showed that the high values of leaves weight / plant were recorded with bio-fertilizer phosphorin with $\mathrm{TiO}_{2}$ nanoparticles spray at the rate of $2 \mathrm{mg} / \mathrm{L}$ in the first season only and with bio-fertilizer nitroben + phosphorin with $\mathrm{TiO}_{2}$ nanoparticles spray treatment at the rate of $2 \mathrm{mg} / \mathrm{L}$ in the second season only.

Table (3). Effect of bio-fertilizer and $\mathrm{TiO}_{2}$ nanoparticles spray on total chlorophyll and leaf area $\left(\mathrm{cm}^{2}\right)$ of turnip plants during 2015/2016 and 2016/2017 growing seasons.

\begin{tabular}{|c|c|c|c|c|c|c|c|c|}
\hline \multirow{3}{*}{$\begin{array}{l}\text { Seasons } \\
\text { Characters } \\
\text { Treatments } \\
\end{array}$} & \multicolumn{8}{|c|}{$1^{\text {st }}$ season } \\
\hline & \multicolumn{4}{|c|}{ Total chlorophyll } & \multicolumn{4}{|c|}{ Leaf area $\left(\mathrm{cm}^{2}\right)$} \\
\hline & \multirow[t]{2}{*}{ Cont. } & \multirow{2}{*}{$\begin{array}{l}\mathrm{TiO}_{2} \\
1 \mathrm{mg}\end{array}$} & \multirow{2}{*}{$\begin{array}{l}\mathrm{TiO}_{2} \\
2 \mathrm{mg}\end{array}$} & \multirow[t]{2}{*}{$\mathbf{X}^{-}$} & \multirow[t]{2}{*}{ Cont. } & \multirow{2}{*}{$\begin{array}{c}\mathrm{TiO}_{2} \\
1 \mathrm{mg}\end{array}$} & \multirow{2}{*}{$\begin{array}{l}\mathrm{TiO}_{2} \\
2 \mathrm{mg}\end{array}$} & \multirow[t]{2}{*}{$\mathbf{X}^{-}$} \\
\hline $\begin{array}{l}\text { Bio- } \\
\text { fertilizer }\end{array}$ & & & & & & & & \\
\hline Control & 45.3 & 50.8 & 52.3 & 49.5 & 72.3 & 75.0 & 75.3 & 74.2 \\
\hline Nitroben & 46.3 & 51.7 & 53.7 & 50.6 & 78.3 & 84.0 & 86.7 & 83.0 \\
\hline Phosphorin & 46.3 & 54.3 & 55.7 & 52.1 & 79.7 & 91.0 & 93.0 & 87.9 \\
\hline $\begin{array}{l}\text { Nitro. + } \\
\text { Phos. }\end{array}$ & 48.3 & 51.0 & 52.0 & 50.4 & 89.3 & 92.0 & 100.3 & 93.9 \\
\hline \multirow[t]{2}{*}{$\mathbf{X}^{-}$} & 46.6 & 52.0 & 53.4 & & 79.9 & 85.5 & 88.8 & \\
\hline & \multicolumn{8}{|c|}{$2^{\text {nd }}$ season } \\
\hline Control & 45.7 & 48.0 & 49.0 & 47.6 & 81.7 & 84.0 & 85.3 & 83.7 \\
\hline Nitroben & 47.3 & 53.0 & 54.7 & 51.7 & 93.7 & 100.7 & 103.7 & 99.3 \\
\hline Phosphorin & 47.0 & 52.7 & 53.0 & 50.9 & 92.0 & 104.7 & 103.3 & 100.0 \\
\hline $\begin{array}{l}\text { Nitro. }+ \\
\text { Phos. }\end{array}$ & 46.3 & 52.0 & 54.7 & 51.0 & 99.0 & 109.7 & 114.7 & 107.8 \\
\hline $\mathbf{X}^{-}$ & 46.6 & 51.4 & 52.8 & & 91.6 & 99.8 & 101.8 & \\
\hline \multicolumn{3}{|c|}{ L.S.D. (0.05) for: } & Sea. 1 & Sea. 2 & & & Sea. 1 & Sea. 2 \\
\hline \multicolumn{3}{|l|}{ Bio-fertilizer } & NS & NS & & & 3.25 & 5.87 \\
\hline \multicolumn{3}{|l|}{$\mathrm{TiO}_{2}$} & 2.581 & 1.202 & & & 4.32 & 3.11 \\
\hline \multicolumn{3}{|l|}{$\mathrm{Bio} \mathrm{X} \mathrm{TiO}_{2}$} & NS & NS & & & NS & NS \\
\hline
\end{tabular}




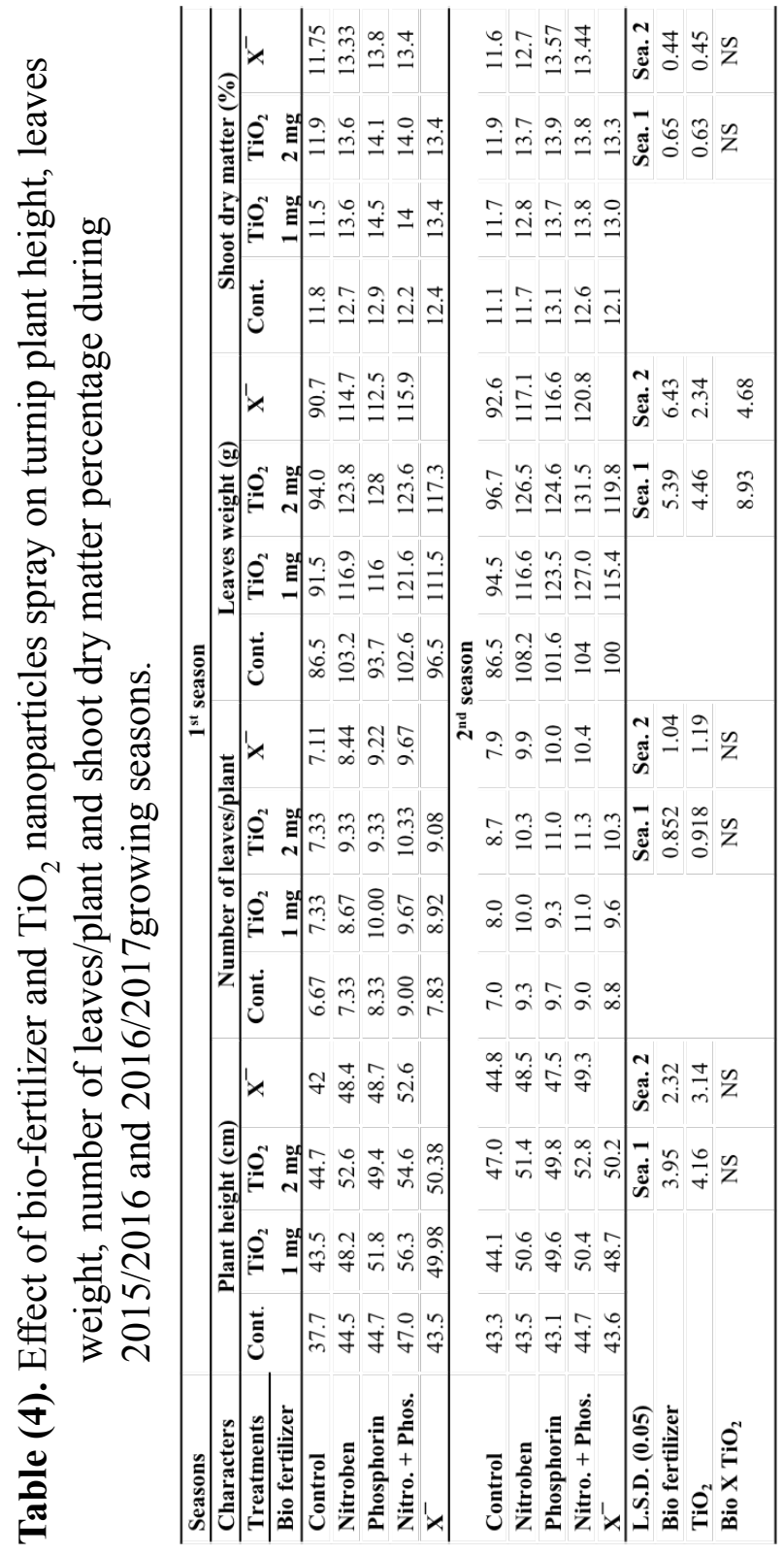

Egyptian J. Desert Res., 69, No. 1, 87-107 (2019) 


\section{Root and Yield Parameters}

Root and yield parameters; i.e., root length, diameters, dry matter percent yield of meter square and total yield/fed, were presented in tables (5 and 6). The obtained results indicated that there were significant positive effects for both bio-fertilizer amendments and spray application treatments on all investigated yield parameters. From the data, the following could be remarked:

1. Bio-fertilizer phosphorin treatment recorded the highest values of root length and yield of $\mathrm{m}^{2}$ in the first season only and the highest values of root diameter in both seasons. Moreover, mixing nitroben + phosphorin treatment recorded the highest values of root length, weight and yield of $\left(\mathrm{m}^{2}\right)$ in the second season only and highest values of root dry matter and total yield in both seasons. In general, no significant differences were recorded between all bio-fertilizer treatments for all parameters as compared with the control (without addition) in both growing seasons. The positive effect of bio-fertilizer application may be due to that it improves effective mobilization of major plant nutrients like $\mathrm{N}, \mathrm{P}$ and $\mathrm{K}$ and other minor nutrients needed by the plant. Also, these beneficial microorganisms are also known to secrete plant growth promoting substances like IAA, GA, cytokinins and vitamins for the improvement of crop growth, yield and quality (Natarajan, 2007; Sreenivasa et al., 2010; Kumar et al, 2013 and Mehdizadeh et al, 2013). These results are in same line with those reported by Bashyal (2011), who found that the application of nitrogen along with the bio-fertilizer significantly increased morphological, yield and quality characters as compared to the application of nitrogen without bio-fertilizers.

2. The highest values of root length, diameters, dry matter percent yield of meter square and total yield/fed, were recorded with $\mathrm{TiO}_{2}$ nanoparticles spray at the rate of $2 \mathrm{mg} / \mathrm{L}$, followed by the rate $1 \mathrm{mg} / \mathrm{L}$. Significant positive differences were found between all $\mathrm{TiO}_{2}$ nanoparticles spray treatments compared with the control treatment (spray by tap water) in both growing seasons. The positive effect of $\mathrm{TiO}_{2}$ nanoparticles application may be due to that it increases the photosynthetic activities in plants and promotes crop growth metabolism. The results are in the same line with studies reported that nano- $\mathrm{TiO}_{2}$ can promote plant photosynthesis and nitrogen metabolism and then greatly improve growth and yield (Hong et al., 2005; Zheng et al, 2005 and Yang et al., 2007).

Egyptian J. Desert Res., 69, No. 1, 87-107 (2019) 


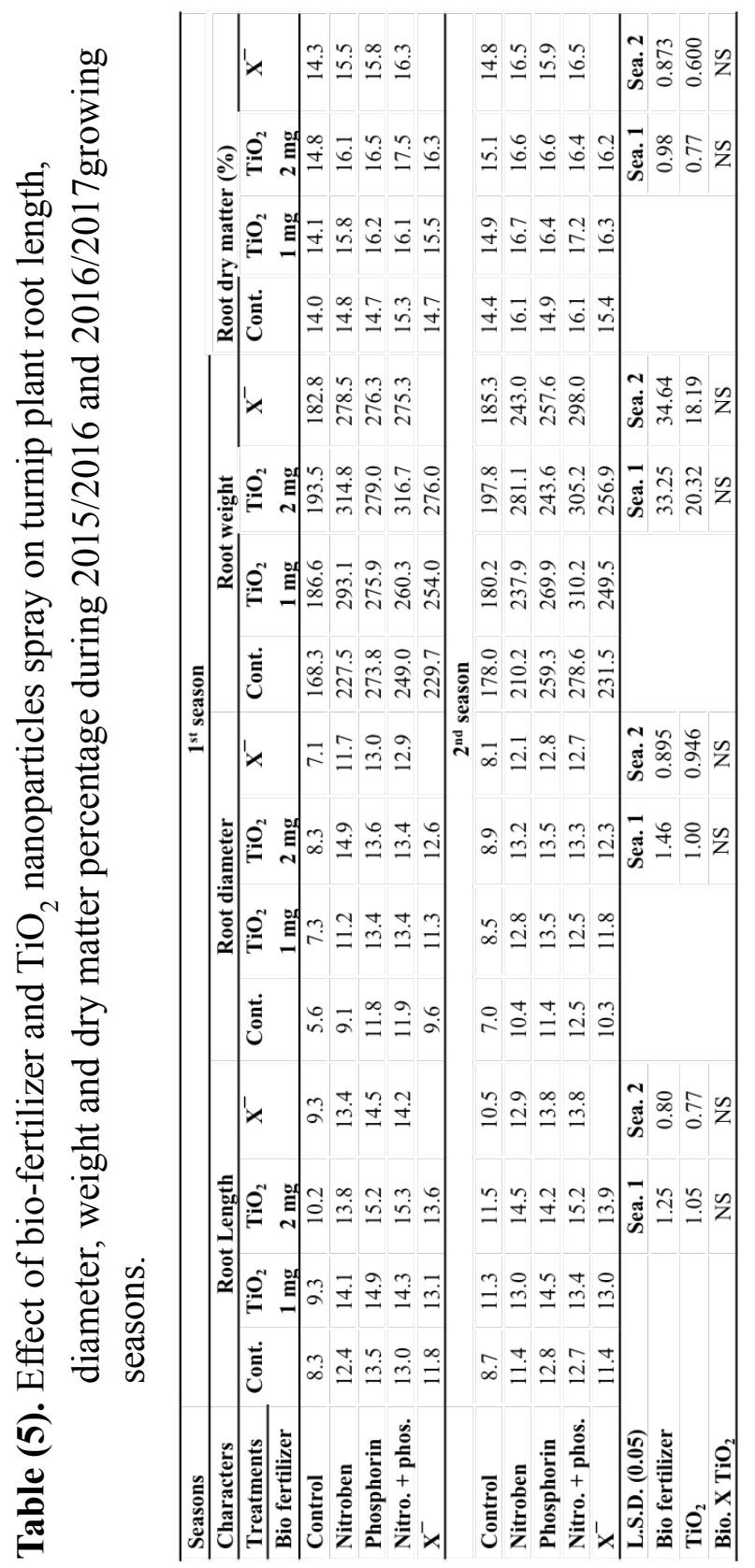

Egyptian J. Desert Res., 69, No. 1, 87-107 (2019) 
Table (6). Effect of bio-fertilizer and $\mathrm{TiO}_{2}$ nanoparticles spray on total chlorophyll and leaf area $\left(\mathrm{cm}^{2}\right)$ of turnip plants during 2015/2016 and 2016/2017 growing seasons.

\begin{tabular}{|c|c|c|c|c|c|c|c|c|}
\hline \multirow{2}{*}{$\begin{array}{l}\text { Seasons } \\
\text { Characters } \\
\end{array}$} & \multicolumn{8}{|c|}{$1^{\text {st }}$ season } \\
\hline & \multicolumn{4}{|c|}{ Root yield $\left(\mathrm{m}^{2}\right)$} & \multicolumn{4}{|c|}{ Total root yield/fed } \\
\hline Treatments & \multirow[t]{2}{*}{ Cont. } & \multirow{2}{*}{$\begin{array}{l}\mathrm{TiO}_{2} \\
1 \mathrm{mg}\end{array}$} & \multirow{2}{*}{$\begin{array}{l}\mathrm{TiO}_{2} \\
2 \mathrm{mg}\end{array}$} & \multirow[t]{2}{*}{$\mathbf{X}^{-}$} & \multirow[t]{2}{*}{ Cont. } & \multirow{2}{*}{$\begin{array}{l}\mathrm{TiO}_{2} \\
1 \mathrm{mg}\end{array}$} & \multirow{2}{*}{$\begin{array}{l}\mathrm{TiO}_{2} \\
2 \mathrm{mg}\end{array}$} & \multirow[t]{2}{*}{$\mathbf{X}^{-}$} \\
\hline Bio-fertilizer & & & & & & & & \\
\hline Control & 2.30 & 2.80 & 2.70 & 2.60 & 9.20 & 11.2 & 10.8 & 10.4 \\
\hline Nitroben & 2.27 & 3.10 & 3.51 & 2.96 & 9.07 & 12.4 & 14.0 & 11.8 \\
\hline Phosphorin & 3.24 & 3.56 & 3.69 & 3.50 & 12.9 & 14.2 & 14.7 & 13.9 \\
\hline Nitro. + Phos. & 3.04 & 3.69 & 3.69 & 3.47 & 12.1 & 14.7 & 14.7 & 13.9 \\
\hline \multirow[t]{2}{*}{$\mathbf{X}^{-}$} & 2.71 & 3.29 & 3.40 & & 10.8 & 13.1 & 13.5 & \\
\hline & \multicolumn{8}{|c|}{$2^{\text {nd }}$ season } \\
\hline Control & 2.20 & 2.57 & 2.66 & 2.47 & 8.80 & 10.3 & 10.6 & 9.90 \\
\hline Nitroben & 2.50 & 2.90 & 3.19 & 2.86 & 10.0 & 11.5 & 12.7 & 11.4 \\
\hline Phosphorin & 3.01 & 3.45 & 3.37 & 3.28 & 12.0 & 13.8 & 13.4 & 13.1 \\
\hline Nitro. + Phos. & 2.97 & 3.56 & 3.47 & 3.33 & 11.8 & 14.2 & 13.8 & 13.3 \\
\hline $\mathrm{X}^{-}$ & 2.67 & 3.12 & 3.17 & & 10.6 & 12.4 & 12.6 & \\
\hline L.S.D. (0.05) & & & Sea. 1 & Sea. 2 & & & Sea. 1 & Sea. 2 \\
\hline Bio-fertilizer & & & 0.37 & 0.34 & & & 1.47 & 1.35 \\
\hline $\mathrm{TiO}_{2}$ & & & 0.22 & 0.18 & & & 0.8 & 0.73 \\
\hline $\mathrm{Bio} \mathrm{X} \mathrm{TiO}_{2}$ & & & NS & NS & & & NS & NS \\
\hline
\end{tabular}

\section{Chemical Constituents}

Chemical constituent parameters i.e., $\mathrm{N}(\%), \mathrm{P}(\%), \mathrm{K}(\%)$ and total carbohydrates (\%) are presented in table (7). Obtained results indicated that there are significant positive effects for both bio-fertilizer amendments and spray application on some investigated chemical constituent parameters. From the data, the following could be remarked:

1. Statistical analysis of data in table (7) shows that the highest values of $\mathrm{N}$ $(\%), \mathrm{K}(\%)$ and total carbohydrates were recoded with bio-fertilizer mixture (nitroben + phosphorin) treatment in both growing seasons. The results are in the same trend with those reported by Zaki et al. (2012), who found increasing in vitamin $\mathrm{C}, \mathrm{N}, \mathrm{P}$ and $\mathrm{K}$ in tissues of broccoli leaves and heads in treated plants by bio-fertilizer compared to the untreated plants.

2. The highest values of $\mathrm{N}(\%)$ content were recorded with $\mathrm{TiO}_{2}$ nanoparticles spray at the rate of $2 \mathrm{mg} / \mathrm{L}$ in both seasons, but the same rate of $\mathrm{TiO}_{2}$ treatment recorded the highest values of $\mathrm{P}(\%)$ and total carbohydrates in 


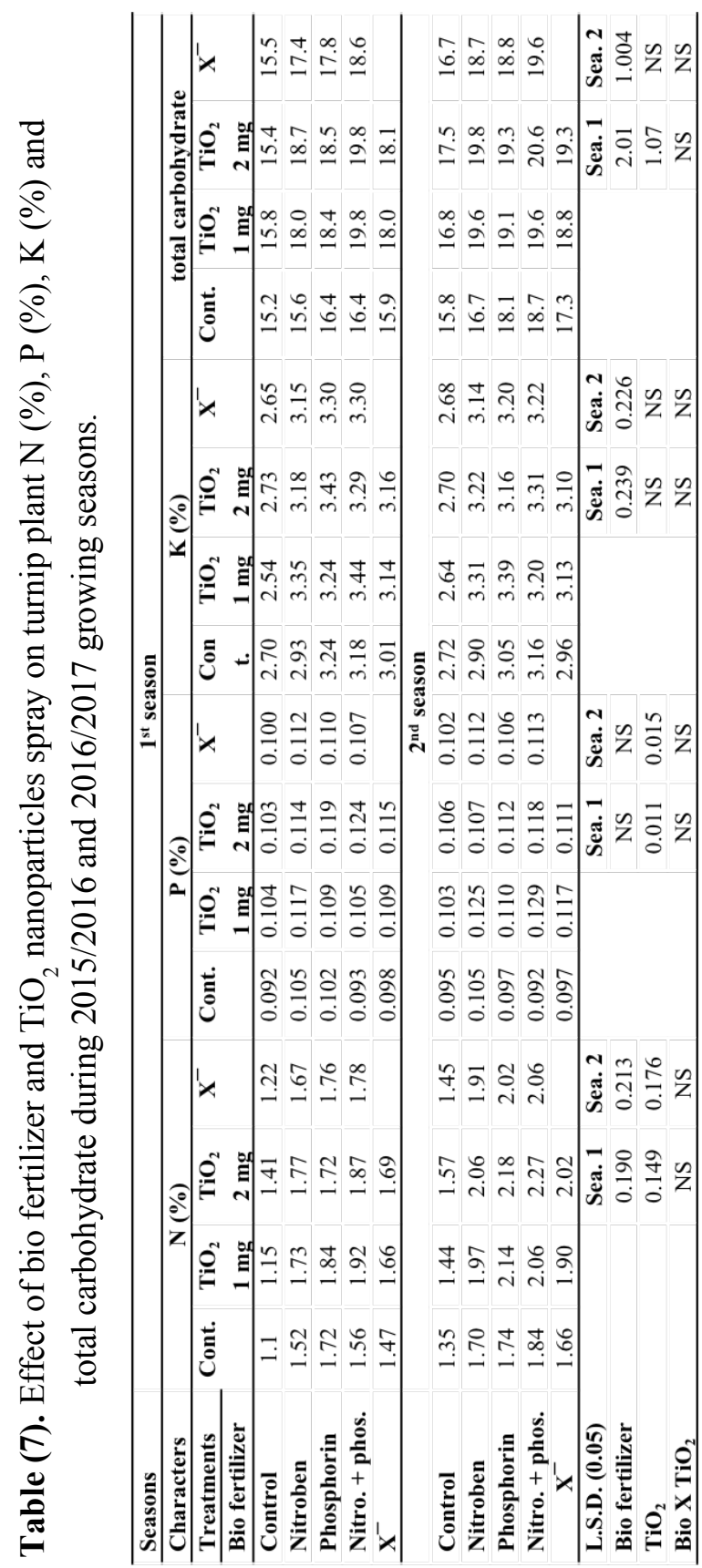

Egyptian J. Desert Res., 69, No. 1, 87-107 (2019) 
the first season only. The positive effect of $\mathrm{TiO}_{2}$ it increases the photosynthetic activities in plants and increases the uptake of nutrients (NPL, 2002 and Gao et al., 2008). They also reported that the application of $\mathrm{TiO}_{2}$ significantly increase correspondent $20 \%$ in grain weight of rice and tomato due to the growth promoting effect of $\mathrm{TiO}_{2}$ nano-particles.

\section{Turnip Pickle Quality}

Pickling is one of the most well-known appreciated method in preserving vegetables because it is an easy method used to slow down the decaying process and so, it could be kept for longer time. Besides, it offers a product which could be used as appetizer. It was important to estimate the effect of bio-fertilizer and $\mathrm{TiO}_{2}$ nanoparticles spray best treatments on the quality of turnip pickle. Thus, texture analysis and sensory evaluation have been chosen to evaluate this quality. The pickling process was done for the best observed treatments as mentioned above which were as following:

- Treatment TNP: Nitroben + phosphorin $+2 \mathrm{mg} / \mathrm{L} \quad \mathrm{TiO}_{2}$

- Treatment TN : Nitroben $+2 \mathrm{mg} / \mathrm{L} \mathrm{TiO}_{2}$

- Treatment TP : Phosphorin $+2 \mathrm{mg} / \mathrm{L} \mathrm{TiO}_{2}$

\section{Texture Analysis of Turnip Pickle}

Texture in pickled vegetables plays an important role in their general acceptability. Therefore, texture of turnip pickle was determined through measuring the hardness value $(\mathrm{N})$. According to the data illustrated in fig. (1), it was found that the hardness value was significantly different among the three turnip pickle treatments, where the TP treatments observed the highest significant hardness value followed by TNP treatments, while the TN treatments had the lowest hardness value, which means the more softness.

\section{Sensory Evaluation of Turnip Pickle}

Consumer acceptability considered an important parameter to evaluate the success of any food product, therefore, sensory evaluation has been used to estimate this parameter. Appearance, color, taste, texture and overall acceptability of turnip pickle treatments under seeking were subjected to be evaluated by 10 trained panelist and the mean score values are given in fig. (2). Results reveal that, there was a significant difference between turnip pickle treatments for both texture and taste parameter, where the TN treatment observed a significant decrement in both taste and texture parameter, followed by TP and TNP treatments, respectively. There was no significant difference in both color and appearance among turnip pickle treatments. The TNP treatments showed a good sensory acceptability where the overall acceptability value was

Egyptian J. Desert Res., 69, No. 1, 87-107 (2019) 
9.8, followed by TP and TN treatments with overall acceptability values of 8.5 and 8.0 , respectively.

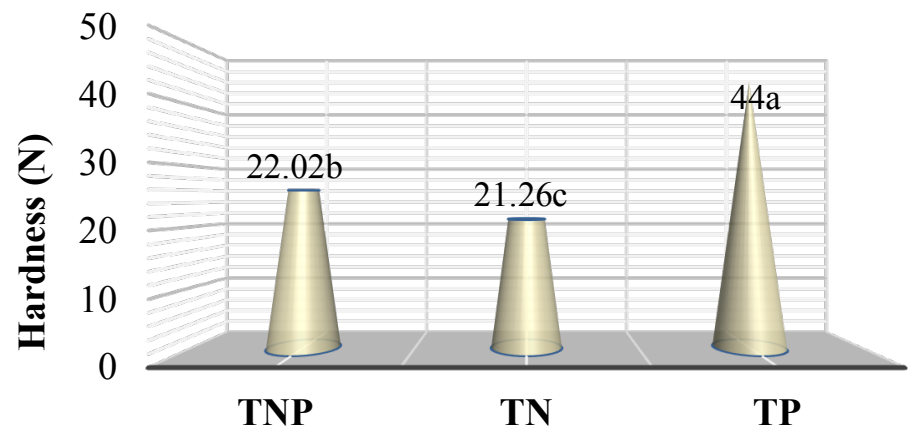

Fig. (1). Effect of bio-fertilizer and $\mathrm{TiO}_{2}$ spray on turnip pickle texture.

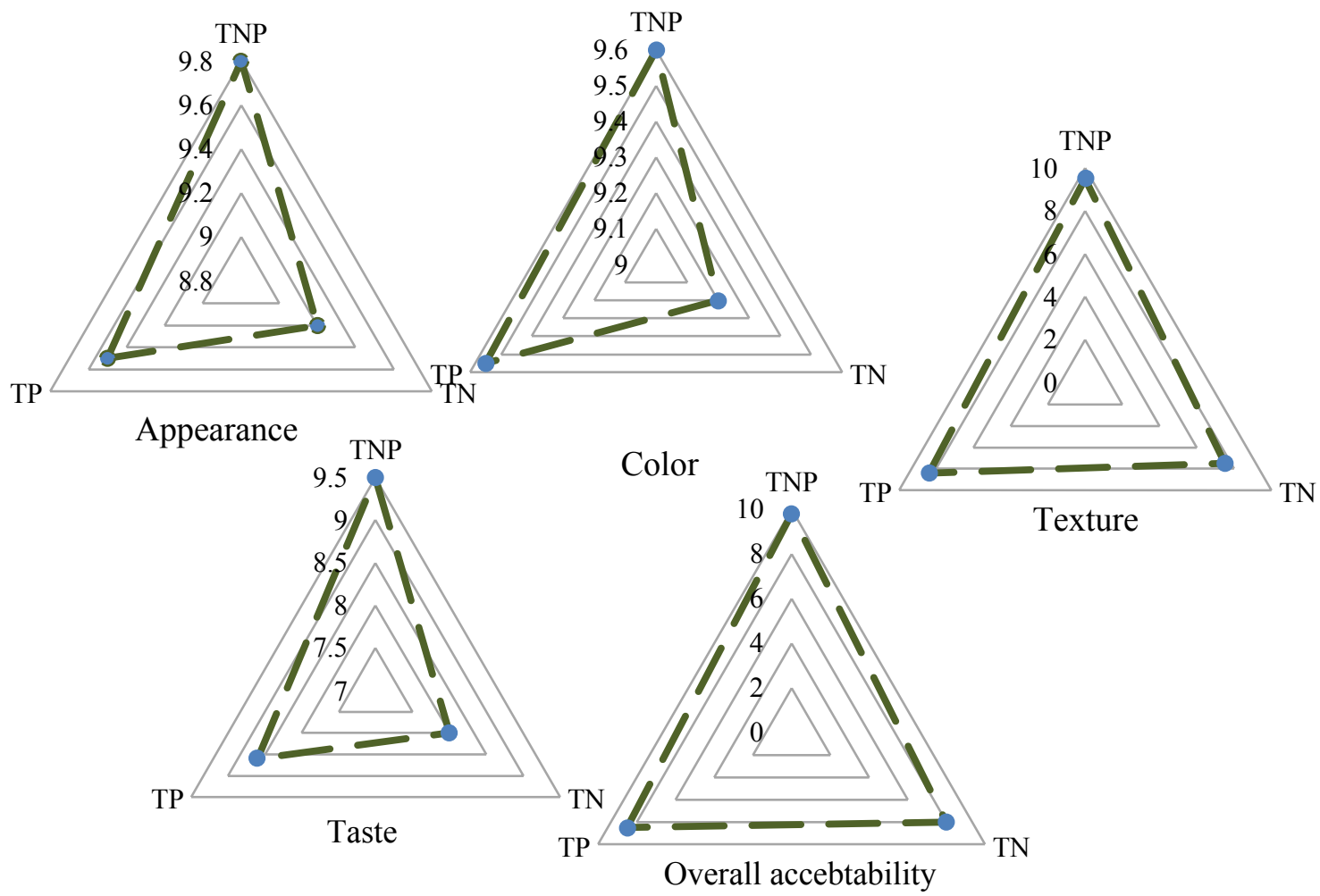

Fig. (2). Effect of bio-fertilizer and $\mathrm{TiO}_{2}$ spray on sensory properties of turnip pickle.

Egyptian J. Desert Res., 69, No. 1, 87-107 (2019) 
The final goal of any agricultural application is to get profitable yield as gain from the invested cost. The agricultural process is mainly economic, especially if value for products was added as pickle process, so the net gain of each pound from the input is important to get the highest rate of revenue. Table (8) shows the calculation of fixed input for all fresh production treatments; fixed cost of one ton of pickle and the total output of one unit of production (fresh and pickle), while table (9) gives the total output for all treatments and investment ratio. It should be noticed that when investment ratio is calculated for pickle production, following equation is applied:

$$
\text { Investment ratio for pickle }=\frac{\left(\mathrm{RY}{ }^{*} \mathrm{~L} \%\right)^{*} \mathrm{P}}{\mathrm{TI}+\left(\mathrm{X}^{*} \mathrm{~N}\right)}
$$

$\mathrm{RY}=$ Total fresh $\operatorname{root} / \mathrm{fed}$

$\mathrm{L}=20 \%$ lost in total weight, fixed lost for pickle processing i.e. Peeling... etc.)

$\mathrm{P}=$ price of one ton of pickle $\quad \mathrm{TI}=$ total input/fed (for each treatment)

$\mathrm{X}=$ fixed cost of one ton pickle $\quad \mathrm{N}=$ No. of tons

Table (8). Fixed input cost and output for fresh or pickled turnip production (LE/fed).

Fresh production cost

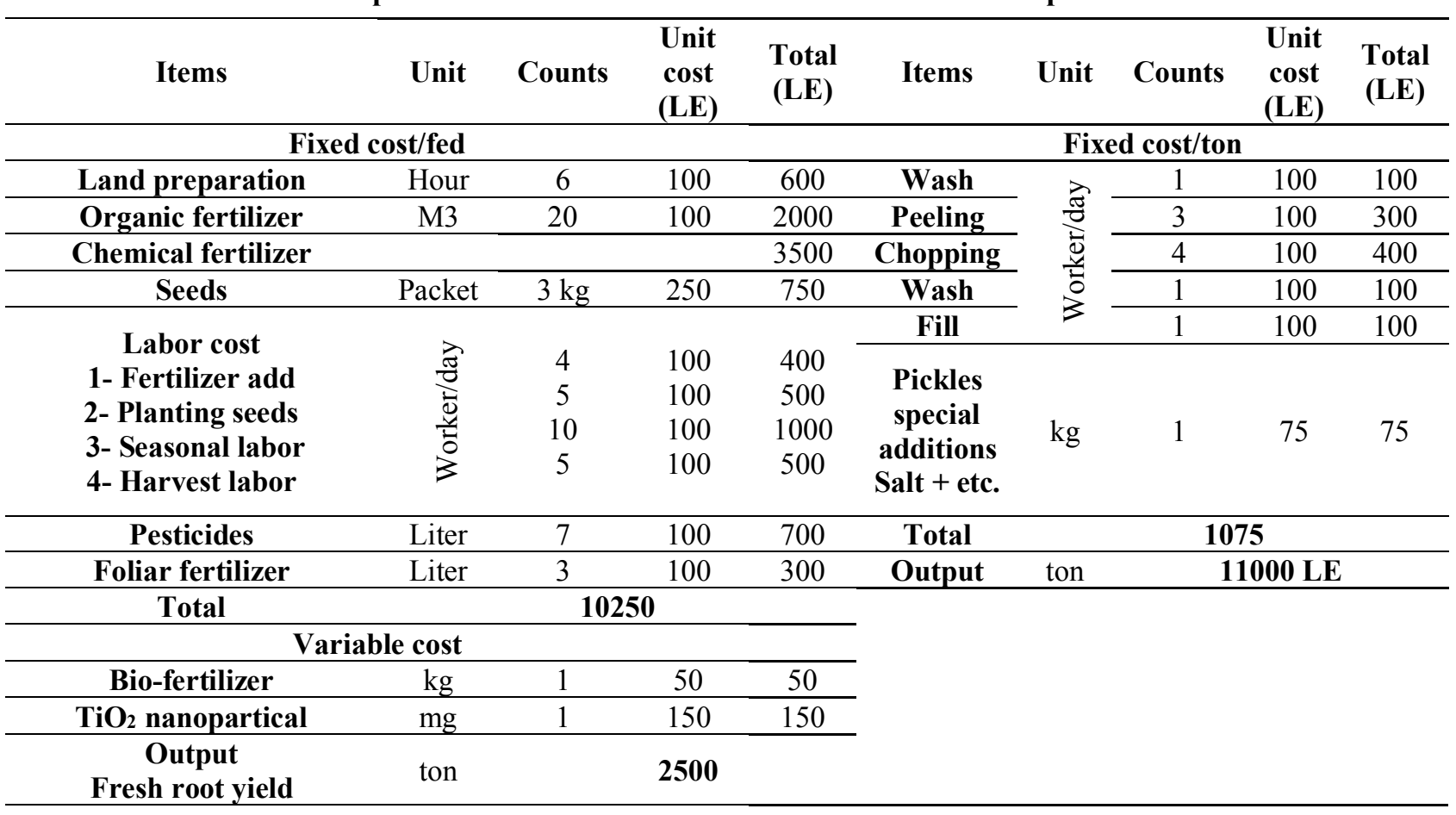

Egyptian J. Desert Res., 69, No. 1, 87-107 (2019) 


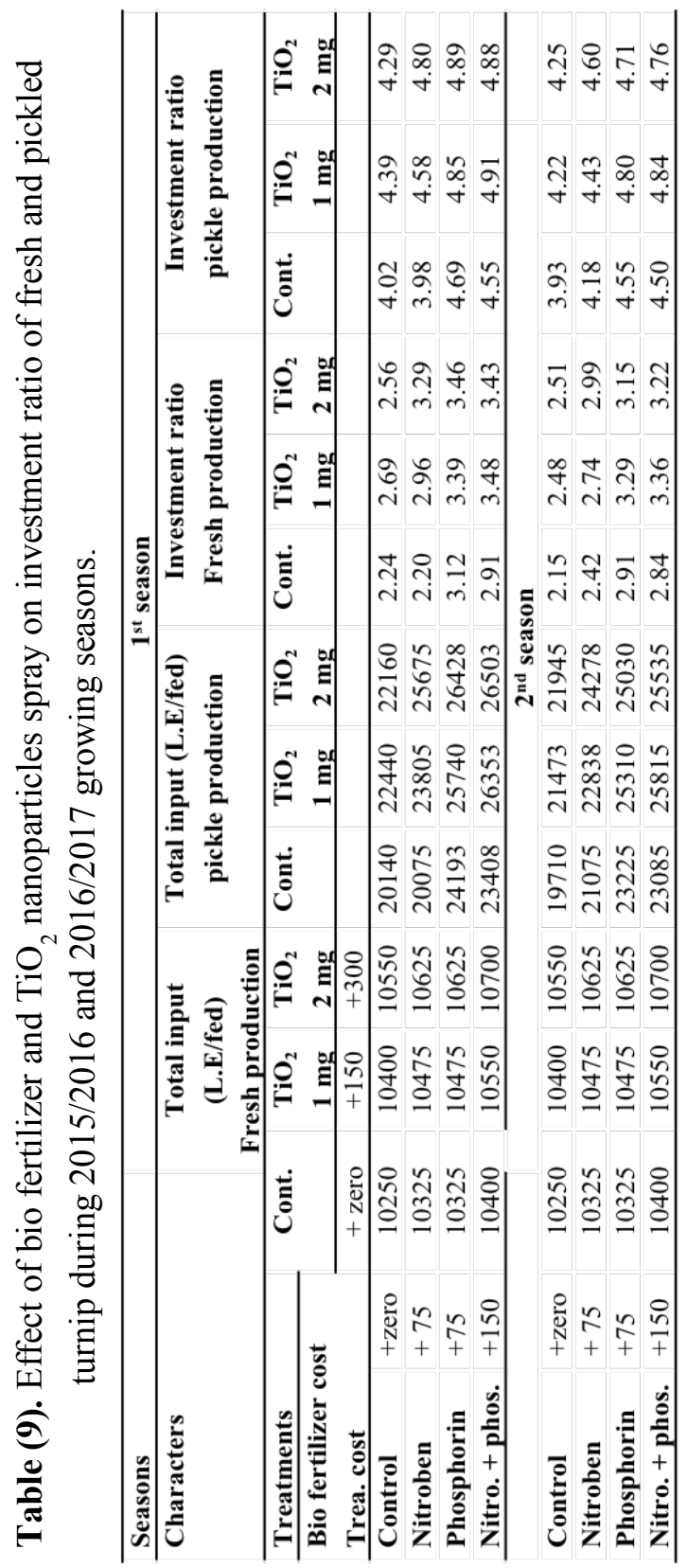

Egyptian J. Desert Res., 69, No. 1, 87-107 (2019) 


\section{REFERENCES}

A.O.A.C. (1990). In: "Official Methods of Analysis". Twelfth Ed. Published by the Association of Official Analytical Chemists, Benjamin, Frankline Station, Washington. DC.

A.A.C.C. (2000). In: "Approved Methods of the American Association of Cereal Chemists". St. Paul, MN, USA.

Ann, M.S., V. Duyn and E. Pivonka (2000). Overview of the health benefits of fruit and vegetable consumption for the dietetics professional: selected literature. J. Amer. Diet. Assoc., 100 (12): 1511-1521.

Abul Hossain, M., M.M. Haque, M.A. Haque and G.N.M. Ilias (2012). Trichoderma-enriched biofertilizer enhances production and nutritional quality of tomato (Lycopersicon esculentum Mill.) and minimizes NPK fertilizer use. Agric. Res., 1 (3): 265-272.

Aghili, F., J. Jansab, A.H. Khoshgoftarmaneshc, M. Afyunic, R. Schulind, E. Frossarda and H.A. Gampera (2014). Wheat plants invest more in mycorrhizae and receive more benefits from them under adverse than favorable soil conditions. Appl. Soil Ecology, 84 (1): 93-111.

Barley, R. (2003). In: "The Smaller the Better (Long but Interesting)". Reason Newsl., 15 pp.

Bashyal, L.N. (2011). Response of cauliflower to nitrogen fixing biofertilizer graded levels of nitrogen. J. Agri. Environ., 12: 41-50.

Brown, J.D. and O. Lilliland (1964). Rapid determination of potassium and sodium in plant material and soil extracts by flame photometer. Proc. Amer. Soc. Hort. Sci., 48: 341-346.

Carmen, I.U., P. Chithra, Q. Huang, P. Takhistov, S. Liu and J.L. Kokini (2003). Nanotechnology: a new frontier in food science. Food Technology, 57: 24- 29.

Cottenie, A., M. Verloo, L. Kickens, G. Velghe and R. Camerlynck (1982). In: "Chemical Analysis of Plants and Soils". Laboratory of Analytical and Agrochemistry. State University, Ghent Belgium, 63 pp.

Das, R., H. Pandey, B. Das and S. Sarkar (2016). Fermentation and its application in vegetable preservation: A Review. Int. J. Food. Ferment. Technol., 6 (2): 207-217.

Fawzy, Z.F., A.M. El-Bassiony, L. Yunsheng, O. Zhu and A.A. Ghoname (2012). Effect of mineral, organic and bio-N fertilizers on growth, yield and fruit quality of sweet pepper. Journal of Applied Sciences Research, 8 (8): 3921-3933.

Egyptian J. Desert Res., 69, No. 1, 87-107 (2019) 
Gao, F., F. Hong, C. Liu, L. Zheng, M. Su, X. Wu, F. Yang, C. Wu and P. Yang (2008). Mechanism of nano. anatase $\mathrm{TiO}_{2}$ on promoting photosynthetic carbon reaction of spinach. Biol. Trace Elem. Res. J., 111: 239-253.

Hong, F., J. Zhou, C. Liu, F. Yang, C. Wu, L. Zheng and P. Yang (2005). Effects of nano- $\mathrm{TiO}_{2}$ on photochemical reaction of chloroplasts of spinach. Biological Trace Element Research, 105: 269-279.

Khashayar, P. (2007). Alternative Medicine, Turnip, Press TV, Tehran.

Klute, A.J. (1986). In: "Methods of Soil Analysis". No. (9), Part 1-Physical and Mineralogical Methods. Am. Soc., Agron., Inc. Soil. Sci., Mad., Wisc., USA.

Kumar, J. Ajay, K.R. Sreeramulu and G. Kushala (2013). Effect of microbial inoculants on the yield of beet-root (Beta vulgaris), Asian J. BioSci., 8: 6:10.

Lu, C.M., C.Y. Zhang, J.Q. Wen and G.R. Wu (2002). Effects of nano material on germination and growth of soybean. Soybean Sci., 21 (3): 168-171.

Mehdizadeh, M., E.I. Darbandi, H. Naseri-Rad and A. Tobeh (2013). Growth and yield of tomato (Lycopersicon esculentum Mill.) as influenced by different organic fertilizers. International Journal of Agronomy and Plant Production, 4 (4): 734-738.

Mingyu, S., H. Fashui, L. Chao, W. Xiao, L. Xiaoqing, C. Liang, G. Fengqing, Y. Fan and L. Zhongrui (2007). Effects of nano-anatase $\mathrm{TiO}_{2}$ on absorption, distribution of light, and photoreduction activities of chloroplast membrane of spinach. Biological Trace Element Research, 118: $120-130$.

Molla, A., M.M. Haque, M.A. Haque and G.N.M. Ilias (2012). Use trichodermaenriched bio fertilizer enhances production and nutritional quality of tomato (Lycopersicon esculentum Mill.) and minimizes NPK fertilizer use. Agric. Res., 1 (3): 265-272.

Moore, D. (1997). Key issues in medium term outlook for titanium and zircon resource. Outlook Conference, Canberra, 4-6 Feb., 23 pp.

Natarajan, K. (2007). Panchagavya for plant. Proceedings of National Conference Glory Gomatha, Dec. 1-3, S.V. Veterinary Univ., Tirupati, p. $72-75$.

Nel, A., T. Xia, L. Madler and N. Li (2006). Toxic potential of materials at the nano level. Science, 311: 622-627.

NPL (Nano-Plant Technology). (2002). In: "Method of Accelerating Metabolism and Growth of Plant Using the Corpuscular of Titanium Dioxide". A handbook. Sun Plus Corp., Korea. 
Page, A.L., R.H. Miller and D.R. Keeney (1982). In: "Methods of Soil Analysis; Part 2. Chemical and Microbiological Properties". American Soc. of Agronomy Publ., Madison, Wisconsin, USA.

Rana, G., N. Katerji, M. Mastrorilli, C.R. Camp, E.J. Sadler and R.E. Yoder (1996). Evapotranspiration measurement of crops under water stress: Evapotranspiration and irrigation scheduling. Proceedings of International Conference, San Antonio, Texas, USA, p. 691-696.

Roco, M.C. (2003). Nanotechnology: convergence with modern biology and medicine. Curr. Opin. Biotechnol., 14: 337-346.

Sheykhbaglou, R., M. Sedghi, M.T. Shishvan and R.S. Sharifi (2010). Effect of nano iron particles on agronomic traits of soybean. Not. Sci. Biol., 2 (2):112-113.

Siuzdak, K., M. Sawczak, M. Klein, G. Nowaczyk, S. Jurga and A. Cenian (2014). Preparation of platinum modified titanium dioxide nanoparticles with the use of laser ablation in water. Royal Society of Chemistry, 6.

Sreenivasa, M.N, M.N. Nagaraj and S.N. Bhat (2010). Beejamruth: A source for beneficial bacteria. Karnataka J. Agric. Sci., 17 (3): 72-77.

Thomas, M.L. and F.G. Hills (1975). In: "Statistical Methods in Agricultural Research". California Univ., Davis 95616, $2^{\text {nd }}$ Printing, p. 67-74.

Thompson, H.C. and W.C. Kelly (1957). In: "Vegetables Crops". 5 ${ }^{\text {th }}$ Ed. ta-ta McGraw-Hill Publishing Ltd; New Delhi, India, p. 338.

Vatansever, S., A. Vegi1, J. Garden-Robinson and C.A. Hall (2017). The effect of fermentation on the physicochemical characteristics of dry-salted vegetables. Journal of Food Research, 6 (5): 32-40.

Yamani, M.I., F.G.A. Hammouh, M.A. Humeid and R.K. Robinson (1999). Production of fermented cucumbers and turnips with reduced levels of sodium chloride. Trop. Sci., 39: 233-231.

Yang, F., C. Liu, F. Gao, M. Su, X. Wu, L. Zheng, F. Hong and P. Yang (2007). The improvement of spinach growth by nano-anatase $\mathrm{TiO}_{2}$ treatment is related to nitrogen photoreduction. Biological Trace Element Research, 119: 77-88.

Zaki, M.F., A.S. Tantawy, S.A. Saleh and Y.I. Helmy (2012). Effect of biofertilization and different levels of nitrogen sources on growth, yield components and head quality of two Broccoli cultivars. Journal of Applied Sciences Research, 8 (8): 3943-3960.

Zheng, L., F. Hong, S. Lu and C. Liu (2005). Effect of nano- $\mathrm{TiO}_{2}$ on strength of naturally aged seeds and growth of spinach. Biological Trace Element Research, 105: 83-91.

Egyptian J. Desert Res., 69, No. 1, 87-107 (2019) 


\title{
تأثير التسميد الحيوي والرش بجزيئات التيتانيوم المتناهية في الصغر على نمو، إنتاجية وجودة المخلل لمحصول اللفت التئن
}

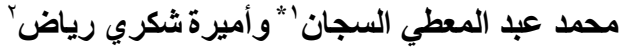

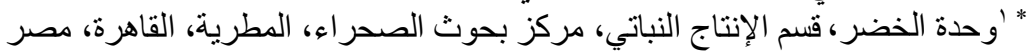 \\ 'وحدة التصنيع الغذائي، قسم الإنتاج النباتي، مركز بركز بحوث الصحر الهُ، المطرية، الفراهة، القاهرة، مصر
}

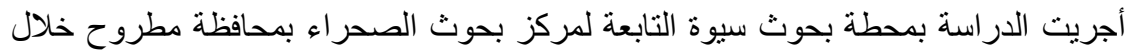

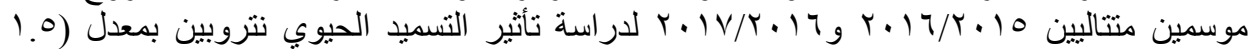

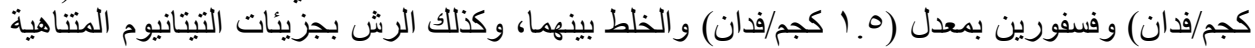

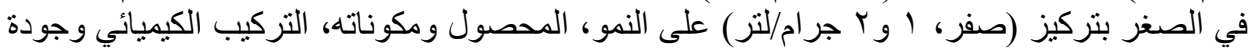

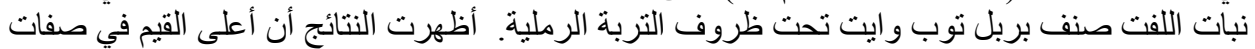

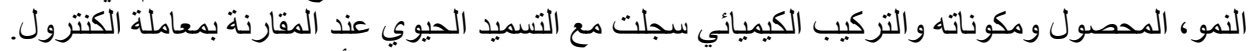

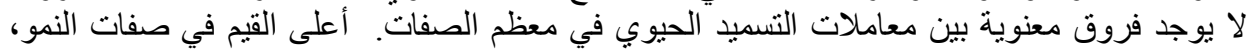

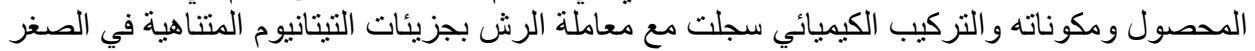

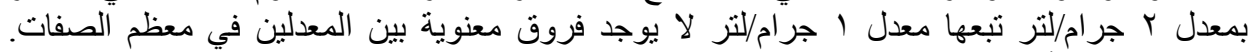

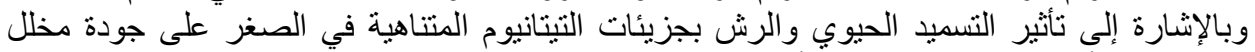

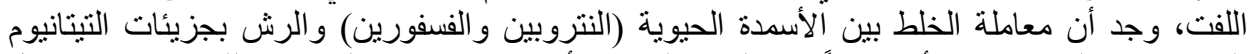

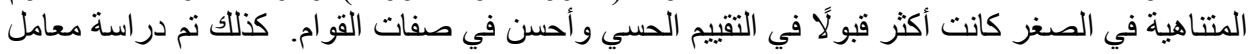
الإستثمار لمعاملات الدراسة. 